\title{
РАЗРАБОТКА ПРОГРАММЫ ПО РАЗВИТИЮ ЭМОЦИОНАЛЬНОЙ САМОРЕГУЛЯЦИ ДЕТЕЙ МЛАДШЕГО ШКОЛЬНОГО ВОЗРАСТА
}

\author{
Мальцева Кристина Игоревна, \\ студентка магистратуры \\ Воронежский государственный педагогический университет (г. Воронеж)
}

\begin{abstract}
Аннотация: в статье рассматривается эмоциональная саморегуляция младших школьников, разработка программа по формированию эмоциональной саморегуляции.

Resume: the article examines the emotional self-regulation of primary schoolchildren, the development of a program for the formation of emotional self-regulation. рефлексия.

Ключевые слова: саморегуляция, младший школьник, поведение, личность, гимнастика, упражнения,
\end{abstract}

Key words: self-regulation, junior schoolchild, behavior, personality, gymnastics, exercises, reflection.

Одна из наиболее сложных задач современного обучения - формирование у учащихся системы саморегуляции, необходимой для эффективного выполнения ими учебной (или иной другой) деятельности.

П. Лафренье утверждал, что ребенок младшего школьного возраста мало осознает свои переживания, с трудом понимает причины его возникновения, а на трудности в школе чаще всего отвечает такими эмоциональными реакциями, как гнев, страх и обида, однако имеет необходимые ресурсы, для того чтобы справиться с данной проблемой [1].

Это подтверждается неумением школьника управлять собой, его дезадаптивным поведением, снижением успеваемости в школе и ухудшением психосоматического здоровья. В то же время, по мнению Е.С. Федосеевой «формирование эмоциональной саморегуляции наиболее эффективно происходит в младшем школьном возрасте и связано оно с представлениями детей о себе, своих возможностях, которые складываются под влиянием взаимодействия с взрослыми и сверстниками. На протяжении всего периода ребенок учится управлять своим поведением, произвольной становится организация его деятельности. Младший школьный возраст обладает глубокими потенциальными возможностями для формирования личностной саморегуляции» $[2$, c.63].

Развитие личности, способной принимать, сохранять цели и следовать им в учебной деятельности, планировать свою деятельность, осуществлять ее контроль и оценку, взаимодействовать с педагогом и сверстниками в учебном процессе к восприятию и пониманию собственных эмоциональных состояний и эмоциональных проявлений других людей, рассматривается как условие успешной ее адаптации в образовательном пространстве.

Нами была разработана программа по совершенствованию эмоциональной саморегуляции младших школьников. Она направлена на то, чтобы помочь детям научиться правильно реагировать на стрессовые ситуации и выходить из возникающих конфликтов; поможет правильно выразить свои чувства и понять, что чувствуют окружающие, развивать эффективные коммуникативные навыки. А так же на снижение школьной тревожности и сохранение психического здоровья детей.

Программа рассчитана на 15 занятий, длительностью 40 минут. Сценарии уроков создаются по единому графику работы с детьми, с целью овладения приемами саморегуляции и формирования необходимых жизненных навыков.

Материалы на занятиях отражают личные проблемы детей этого возраста, поэтому их можно использовать не только в корректирующих целях для проблемных учеников, но и для всех учеников для предупреждения и предотвращения неблагоприятных процессов.

Структура занятий:

1.Вводная часть. Мимическая гимнастика.

- $\quad$ знакомство детей с элементами выразительных движений: мимикой, жестом, позой, походкой;

- $\quad$ работа со словами, обозначающими эмоциональные состояния.

2.Основная часть. Работа по теме занятия.

- $\quad$ рассказ учителя по теме занятия;

- вопросы для обсуждения;

- $\quad$ психологические игры и упражнения.

3. Заключительная часть. Упражнения на релаксацию. Анализ занятия.

- пнятие психо-эмоционального напряжения;

- рефлексия.

Пример занятия:

Тема: «Каким бывает настроение?» 


\section{Цели и задачи:}

- $\quad$ развивать мимические и пантомимические способности;

- $\quad$ познакомить детей с понятием «настроение»;

- $\quad$ создать в группе доверительную обстановку, позволяющую детям проявлять свои чувства и говорить о них;

- $\quad$ обучать детей приемам расслабления.

\section{Ход занятия}

1. Вводная часть. Мимическая гимнастика.

Учитель: А вот и наши знакомые - гномы настроений. Сегодня мы с ними сделаем гимнастику. (Указывает последовательно на гномов, дети называют их чувства, произносят приветствие: «Здравствуй, радостный гном, грустный гном, злой гном и т.д., и мимикой показывают ту, или иную эмоцию).

2. Основная часть. Работа по теме занятия.

Ребята, у вас нередко возникают ситуации, которые портят вам настроение, часто не получается сделать что-то так, как хотелось бы, иногда бывает грустно без близких людей, бывает обидно и т.д. Мы будем учиться справляться с этими проблемами.

У нас бывают разные настроения: когда мы спокойны, то настроение похоже на чистую и прозрачную воду, а когда веселимся, то настроение похоже на праздничный салют. Но бывает, что настроение похоже на грязную воду в луже после дождя. В такие минуты ничего не хочется делать, и мы ждем, когда такое настроение пройдет.

Вопросы для обсуждения:

- Бывало ли у вас такое грустнее настроение? Когда? По какой причине?

- Что вы чувствовали при этом? О чем вы думали?

- Как вы выходили из грустного настроения?

- Нужно ли ждать, когда пройдет плохое настроение?

- Что нужно делать, чтобы оно прошло?

Учим правило.

Учитель открывает детям «правило-секрет»: наше настроение зависит от наших мыслей и действий. Поэтому, если хочешь, чтобы у тебя было хорошее настроение, то перестань себя жалеть, а подумай над вопросом «Как мне выйти из ситуации, которая меня расстроила?»

Затем учитель приводит примеры возможного разрешения ситуации:

- Если я кого-то обидел, то подойду, помирюсь.

- Если я не послушался маму, то попрошу прощения.

- Если я получил «двойку», то сяду за уроки и выучу, что не знал.

3. Заключительная часть.

Предложить детям:

- вести с сегодняшнего дня дневник настроений (выдаются специальные бланки, в которых, изображены пиктограммы настроений и дана таблица дней недели, куда нужно вписывать свое настроение и отмечать, почему оно такое, и в связи с чем возникло);

- если настроение станет плохим, попытаться исправить его при помощи хороших мыслей и действий;

- изготовить и принести на следующее занятие карточки, изображающее три настроения «чистое», «блестящее», «темное».

Упражнение на релаксацию «Насос и мяч».

Учитель: А сейчас найдите свою пару - мы с вами поиграем в насос и мяч. Один из вас - большой надувной мяч, а другой надувает насосом этот мяч. «Мяч» стоит, обмякнув (ноги полусогнуты, корпус отклонен несколько вперед, голова опущена). Начинаем надувать мяч, качаем воздух (движение рук сопровождаются звуком «С-с-с»). А мяч надувается все больше и больше: сначала выпрямляются ноги в коленях, потом туловище, поднимается голова, надуваются щеки, руки разводятся (показ движений). Мяч надут. Тут шланг насоса выдергивается... и из мяча выходит воздух: «Ш-ш-ш». Мяч снова сдулся. Дети, выполняя упражнение, меняются ролями.

Подводится итог занятия.

\section{Литература:}

1. Лафренье, П. Эмоциональное развитие детей и подростков / П.Лафренье.- СПб.: Прайм-Еврознак, 2015. - $250 \mathrm{c}$.

2. Федосеева, Е. С. Формирование личностной саморегуляции младших школьников / Е. С. Федосеева // Грани познания. - 2009. - № 2(3). - С. 63-68 